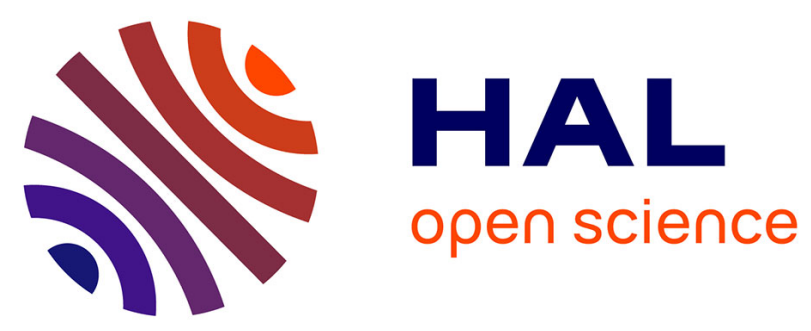

\title{
Global 3D modelling of Martian CO2 clouds
}

Christophe Mathé, Anni Määttänen, Joachim Audouard, Constantino

Listowski, Ehouarn Millour, Francois, Forget, Aymeric Spiga, Déborah

Bardet, Lucas Teinturier, Lola Falletti, et al.

\section{To cite this version:}

Christophe Mathé, Anni Määttänen, Joachim Audouard, Constantino Listowski, Ehouarn Millour, et al.. Global 3D modelling of Martian CO2 clouds. EGU General Assembly 2021, Apr 2021, Virtual Meeting, France. 10.5194/egusphere-egu21-9457 . insu-03446660

\section{HAL Id: insu-03446660 \\ https://hal-insu.archives-ouvertes.fr/insu-03446660}

Submitted on 24 Nov 2021

HAL is a multi-disciplinary open access archive for the deposit and dissemination of scientific research documents, whether they are published or not. The documents may come from teaching and research institutions in France or abroad, or from public or private research centers.
L'archive ouverte pluridisciplinaire HAL, est destinée au dépôt et à la diffusion de documents scientifiques de niveau recherche, publiés ou non, émanant des établissements d'enseignement et de recherche français ou étrangers, des laboratoires publics ou privés.

\section{(c)(1)}

Distributed under a Creative Commons Attribution| 4.0 International License 


\section{Global 3D modelling of Martian $\mathrm{CO}_{2}$ clouds}

Christophe Mathé et al. •

In the Martian atmosphere, carbon dioxide $\left(\mathrm{CO}_{2}\right)$ clouds have been revealed by numerous instruments around Mars from the beginning of the XXI century. These observed clouds can be distinguished by two kinds involving different formation processes: those formed during the winter in polar regions located in the troposphere, and those formed during the Martian year at low- and mid-northern latitudes located in the mesosphere (Määattänen et al, 2013). Microphysical processes of the formation of these clouds are still not fully understood. However, modeling studies revealed processes necessary for their formation: the requirement of waves that perturb the atmosphere leading to a temperature below the condensation of $\mathrm{CO}_{2}$ (transient planetary waves for tropospheric clouds (Kuroda et al., 20123), thermal tides (Gonzalez-Galindo et al., 2011) and gravity waves for mesospheric clouds (Spiga et al., 2012)). In the last decade, a state-of-the-art microphysical column (1D) model for $\mathrm{CO}_{2}$ clouds in a Martian atmosphere was developed at Laboratoire Atmosphères, Observations Spatiales (LATMOS) (Listowski et al., 2013, 2014). We use our full microphysical model of CO 2 cloud formation to investigate the occurrence of these $\mathrm{CO}_{2}$ clouds by coupling it with the Global Climate Model (GCM) of the Laboratoire de Météorologie Dynamique (LMD) (Forget et al., 1999). We recently activated the radiative impact of $\mathrm{CO}_{2}$ clouds in the atmosphere. Last modeling results on Martian $\mathrm{CO}_{2}$ clouds properties and their impacts on the atmosphere will be presented and be compared to observational data.

How to cite: Mathé, C., Määttänen, A., Audouard, J., Listowski, C., Millour, E., Forget, F., Spiga, A., Bardet, D., Teinturier, L., Falletti, L., Vals, M., González-Galindo, F., and Montmessin, F.: Global 3D modelling of Martian CO2 clouds, EGU General Assembly 2021, online, 19-30 Apr 2021, EGU21-9457, https://doi.org/10.5194/egusphere-egu219457, 2021.

Display materials 